\title{
Retooling Agricultural Policies and Programmes for Sustainable Development in Nigeria
}

\author{
Kingsley Akarowhe* \\ Department of Educational Foundations, University of Uyo, Nigeria
}

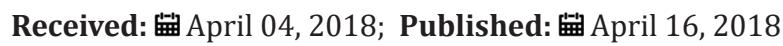

*Corresponding author: Kingsley Akarowhe, Department of Educational Foundations, University of Uyo, Nigeria

\begin{abstract}
Nigeria is one of the developing countries of the world that is blessed with numerous natural resources and fertile arable land for sustainable agriculture, to counter for its increasing population. As a result of global economic downturn, there is a rising needs of Nigeria government to raise the standard of living her citizen through intensive commitment to agricultural programmes and policies. Over the years, as $t$ Nigeria government initiated most of its agric policies and programmes, there tend to be a wide gap on the expected success of these agricultural programmes and polices; and its impacts on the citizens. The forgoing challenges have continued over time without solution. It is on this note that this researcher find it deem fit to investigate the challenges facing agricultural policies and agricultural programmes in the paces of sustainable development in Nigeria. The paper explains the meaning of the core concepts: agriculture; agricultural policies; and programmes; roles of agricultural policies/programmes; and challenges facing agric policies/programmes. The paper also went further in mapping out ways of retooling agric policies/ programmes for it to yield their objectives/goals. It was recommended among other that the government of Nigeria should ensure adequate financial backing of agricultural programmes and policies which will assist by ensuring these agric related programmes are not hampered in the actualization of their targeted objectives.
\end{abstract}

Keywords: Agricultural policies; Agricultural programmes, Sustainable development Challenges; Retooling

\section{Introduction}

Agriculture is the cultivation of the land and rearing of animals for the benefit of man. The cultivation of the land and rearing animal by the farmer(s) (an individual(s)) has far reaching attributes to the development of the society he live. Agriculture is the creation of outputs for the satisfaction of man. The output are products, goods and services of the agricultural sector, that helps to improve, sustain and better the live of man in any society; and also contributes to both the GDP (Gross Domestic Product) and GNP (Gross National Product) in aggregate. Agriculture is a channel of alleviating mass unemployment; ensure income redistribution; means of food sustenance to an anticipated population of the Nigerian society. Due to the important of agriculture in sustainable development in terms of provision of food and income to a large number of the farmers, what happen in the agric-sector is of prior attention to Nigerian society. Agricultural policies and programmes are path way for enhancing agricultural productivity. Agricultural policies are pre- determined goals, objectives and pathway set by an individual or government for the purpose of achieving a specified outcome, for the benefit of the individual(s), society and the nations' economy at large. In Nigeria, agricultural policy include Land Use Act of 1978. Agricultural policies are pathways of improving the activities involve in cropping, livestock, forestry, processing and marketing of agricultural product. Agricultural policies take into consideration the primary, secondary and tertiary processes in agricultural production. Agricultural policy is defined as a public policy that conveys the decision to pursue a specified course of action aimed at improving agricultural practices, by ensuring output growth and the overall development of the agricultural sector [1].

Agricultural programmed is an innovative outfit by an individual(s) or government(s), in improving the acts/processes of cultivating the land and rearing of animals in order to raise standard of the living of the individual(s) and the nation at large. 
Agricultural programmes consist of body of process set by the government of a nation, to reform the agricultural sector so as to increase productivity of the sector for sustainable development and better-life for the citizens. Agricultural programmes are long-term prospect designed to improve the way animals are reared and crops are cultivated. In Nigeria agricultural programmes can be refer to as an outfit embarking upon by the government in the agricultural sector that is intended to ensure meaningful contribution to the development of the nation; and also better the life of the average Nigeria citizens. Example of agricultural programmes in Nigeria includes Green Revolution Programmed (GRP) and Agricultural Development Projects (ADPs) among others. Agricultural policies and programmers are officially designed in sustaining and bettering the lifes of individuals in any society and also contribute to both the GDP (Gross Domestic Product) and GNP (Gross National Product) in aggregate. Agricultural programmes and policies are strategies and mechanism which helps government to carry out set goals and objective in order to improve the agricultural sector in the shortrun and in the long-run the larger society as a result of the positive impacts of such programmes and policies. In contemporary society, agricultural policies and programmes have the following objectives.

\section{Self-Sufficient}

Agricultural policies and programmes are geared to make the nation economy sufficient in the production of agricultural product such as crops (coco, oil palm and so forth) and animals (goats, and hens among others), which will help to counter for the consumption need of citizens in a particular nation. In light of the above, agricultural policies and programmes are projected avenues to make a nation not to over dependent on other countries agric and agro related product.

\section{Social Economy}

Agric policies and programmes enhance and better the life of every citizen, in terms of provision of cash for the sustenance of the individual. Through agricultural policies and programmes the welfare of the citizens will be improved and, hence bridging the gap between the rich and the poor through equitable distribution of income between the national of the country.

\section{Foreign Exchange}

Agricultural policies and programmes does not only enhances the domestic economy by production of product to satisfy the immediate need of the individual in the society but also produce for export to other nations of the world. This also assists in cash inflow into the domestic economy through foreign exchange earnings.

\section{Dual Collaboration}

Numerous agricultural policies and programmes are designed to create a strong synergy between the private and the public sector of the economy. Government often formulates policies and programmes to open the floor for the private sector to contribute to the economy of the nation especially the agricultural sector. This will facilitates research, innovation, provision of facilities such as farm inputs, and good roads among others.

\section{On-going Challenges Facing Agricultural Policies and Programmes}

Over the years, agricultural policies and programmes in Nigeria has not achieved its objectives due to the following bedeviling challenges.

\section{Lack of adequate funding}

Funding in terms of financial allocation is an incent zing factor to achieve a given set of goals/objectives. Finance is often regarded as the power house for any project or obligation that is of prior importance [2]. In Nigeria, most agricultural programmes lack sufficient funds, in carrying out their stated goals. In consonance with the forgoing [3] supplemented that inadequate and untimely fund release by all tiers of government, the lack of funds to procure processing machinery and equipment, and the absence of state and local government implementation committees. Overtime, this has induces non-completion in some agric programme and policies; while in some other cases has impede the smooth process of achieving the targeted objectives of agricultural policies and programmes. This often in the long-run hinder the growth of the sector in terms of ensuring agricultural product are produced to cater for the nations' domestic and foreign.

\section{Embezzlement, misappropriation of fund}

Mismanagement is a major challenge of agriculture in Nigeria [2]. Embezzlement and misappropriation are integral part of corruption in any society. In most agricultural policies and programmes, funds set-aside for specific programmes are often diverted for other function; and in other cases misuse of fund is often witness, this has resulted in lack of implementation of stated goals and objectives. Misappropriation and embezzlement are interwoven variable that create setbacks in the process and processes of implementation and actualization of major agricultural policies and programme in Nigeria. Due to embezzlement, misappropriation of fund most agricultural policies and programmes are often hindered, this invariably retards development of the sector and the economy at large in a particular country [4].

\section{Lack of sufficient agricultural extension service}

In any agricultural sector extension service helps in providing and disseminating proven agricultural information to the farmers. Such information regards ways of improving productivity by farmers. For a successful agricultural system extension service plays a vital role of enlighten individuals that are involve in agricultural practices. Lack of sufficient extension services was witness in most agricultural policies and programmes, examples was indicated in Better Life Programme, this makes the programme not to yield its needed result; and also to last longer as anticipated. In some 
other cases, when extension services are provided, there is always lack of adequate equipment/facilities to effectively achieve the set objectives. In same similitude [5-7] found that the agricultural extension services in Nigeria also suffer from inadequate facilities and input supply.

\section{Unclear/undefined objectives}

Unclear or undefined objectives of any programme or policies in any society is an initiator of its' own failure. In Nigeria, most agricultural policies and programmes are unclear in their stated objectives, this resulted some of their pit-falls. Most agric programmes and policies on the parts of government that formulated them witness undefined objectives, this narrow their objectives and subsequently lead to wastage of effort. This underlining factor, overtime make government policies on agriculture not to be stable [6]. Unclear/undefined objectives may be due to lack of policy accountability [5]. Nigeria suffers from policy instability driven by high rate of turnover of programmes and personnel, which in turn has made the application of policy instruments unstable [5].

\section{Role conflict among various agric policies/programmes}

For actualization of a particular agric policy or programme, it must be free from role conflict with other policies. This is due to the fact that such programme will not play it role effectively due to shared function. In other words, such programme will have a misplaced priority. In Nigeria, role conflict among various agricultural policies and programmes make a specific policies or programme to echoes on another in terms of their area of functioning. Notable role conflict in agricultural programmes and policies in Nigeria was the Land Use Act and Operation Feed the Nation. Such role-conflict retrogress the implement and actualization of both programmes and policies.

\section{Retooling Agricultural Policies and Programmes for Sustainable Development}

The following are some of the ways of retooling agricultural policies and programmes to enhance sustainable development in Nigeria.

\section{Agricultural extension service}

The role of agricultural extension servicecannotbeoveremphasis in an agricultural sector, due to their task of dissemination of proven agricultural information to farmers, based on proven research. Such agricultural information ranges from ways of dealing with pest/disease infestation, maintaining soil fertility, and dealing with deforestation among others. Additionally, extension services help to provide farmers with improved seedling varieties, fertilizers and farm implements. Agricultural extension service helps farmers to key-in to most agricultural policies and programmes, given the fact that agricultural policies and programmes are geared toward increasing agricultural productivity in aggregate. When effective extension services are provided to farmers, they tends to surmount challenge often encounter ranging from pest/disease infestation among others, hence inducing then to make increase yield of harvest which in monetary terms will increase income for farmer over a given farming season. In light of the forgoing, farmers tends on aprior aid the success of agric policies and programmes with the help of extension services provided for them, which in the long-run increase sustainable development of the nation in particular and actualization of agric policies and programmes.

\section{Provision of sufficient funds}

Effective and efficient execution of any project, policy or programme sufficient fund should be made available. Government through her yearly budget should endeavour to benchmark sufficient fund and disburse it to the agric sector. For any policies and programme to yield its' robust benefit to citizens and the nation at large which is a key to sustainable development sufficient funds should be provided by the government and other stakeholders in the agricultural sector to ensure the implementation of agricultural policies and programmes. This will ensure that no stone is left unturned in the process of implementing agric policies and programmes for it to achieve its' a major success. Moreover, private sector (agencies and organisations) should always ensure they play a part in assisting in sustaining agric policies and programmes in terms of funding and supplying need implement that would ensure successful accomplishment of particular policy/programme which will pave way for sustaining development.

\section{Clear/defined objectives}

For agricultural policies/programme to enhance sustainable development, these agric policies and programmes should be clear/defined objectively. In other words, stakeholders in the agric sectors especially policies/programmes inventor/architect should always ensure that the path ways for the innovated policy for agricultural development should be clear, in other for it to yield its needed objectives which are often than not a pivotal for national development. Agricultural policies/programme can be given defined/clear objective through a process of settingup functional boundaries which a given policies/programme is expected to perform so as not to have a functional/role conflict with other policies/programme. Through clear/defined objective of agricultural policies/programme, stakeholders in the agricsector would be able to articulate and predict the end result of their policies/ programmes; and to a large extent it successes; and lastly, its contribution to the agric-sector and the nation at large in terms of its' contribution to sustainable development.

\section{Collaboration}

Collaboration is an avenue of shared values. Such values include information and other resources (material/human) that assist an organization to achieve a given goal. In the agricultural industry collaboration is a vital tool for which agricultural policies are formulated, implemented and achieved. In other words, for a 
successful agricultural programmed and policies to thrive keen collaboration between the private and the public sector should be given priority. This will go a long way to bridge communication gaps in terms of the private sector contributing its part in the implementation process.

\section{On-the-job training}

On the job-training is a venue used by employer of labour to equip employees with skills and disposition that would assist them to be productivity in the discharge of their job. In any organization, establishment or sector of an economy on-the-job training is an important strategy to increase aggregate workers performances. In Nigeria, government and relevant stakeholders in the agricultural sector should assist in ensuring that agricultural personnel are given on-the-job training, this will pave way for workers to ensure effective actualization of the agric policies and programmers. The Nigeria government should make provision for in-service-training of agricultural personnel in the Ministry of Agriculture, which will ensure that agricultural officials are well equipped to man the entire processes of implementing these agricultural policies and agricultural programmes.

\section{Conclusion and Recommendations}

In Nigeria, inspire of the bless arable fertile land for agriculture, the nation is faced with problems of harnessing its meaningful agricultural policies and programmes to improve the condition of the agricultural sector overtime. In light of the findings of this research paper, the researcher wish to conclude that, if the Nigerian government adopt the solution insight and recommendations made, agricultural policies and programmes will yield its adverse benefits to the agricultural sector in the short-run and the Nigerian society in the long-run in terms of sustainable development.

a) The government of Nigeria should ensure adequate financial backing of agricultural programmes and policies. This will assist ensuring that agricultural related programmes are not hampered in the process of ensuring the actualization of their targeted objectives.

b) Internal auditing should be regularly done in the agricsector to check if there is corruption, embezzlement and misappropriation of fund in the process of carrying out agricultural programmes and policies. This will assist in persecution of officials involved in such act, hence reducing further occurrence.

c) Public awareness/enlighten programmes should be in organized by non-governmental agencies and the government in particular, through the mass media. This will help in actualization of agric policies and programmes.

\section{References}

1. Eyo EO (2005) Agricultural Development in Nigeria Plans, Policies and programmes. Best Printing Business Press, Uyo, Nigeria, 42-43.

2. Abutu PO (2014) Challenges of Agriculture in Nigeria Economy: A Bane to Food Security Mismanagement is also a major challenge of agriculture in Nigeria. IOSR Journal of Agriculture and Veterinary Science 7(5): 1821.

3. Akarowhe K (2017) Information Communication Technology in the Educational System of the Third World Countries as a Pivotal to meet Global Best Practice in Teaching and Development. America Journal of Computer Science and Information Technology.

4. Ebong OV (2007) Agribusiness Management in Developing Economy: the Nigeria Perspective. Calabar: Robetminder International Publishers, USA.

5. Federal Ministry of Agriculture and Rural Development-FMARD (2016) The Agriculture Promotion Policy (2016-2020): Building on the Successes of the ATA, Closing Key Gaps. Policy and Strategy Document.

6. Orumana JA (2000) Economics for Senior Secondary Schools and Colleges. Dovina Ventures, Nigeria.

7. Philip D, NKonya E, Pender J,Oni AO (2009) Constraint to Increasing Agricultural Productivity in Nigeria : A Review. Garki: International Food Policy Research Institute.

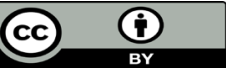

This work is licensed under Creative Commons Attribution 4.0 License

To Submit Your Article Click Here: Submit Article
DOI: 10.32474/CIACR.2018.02.000129

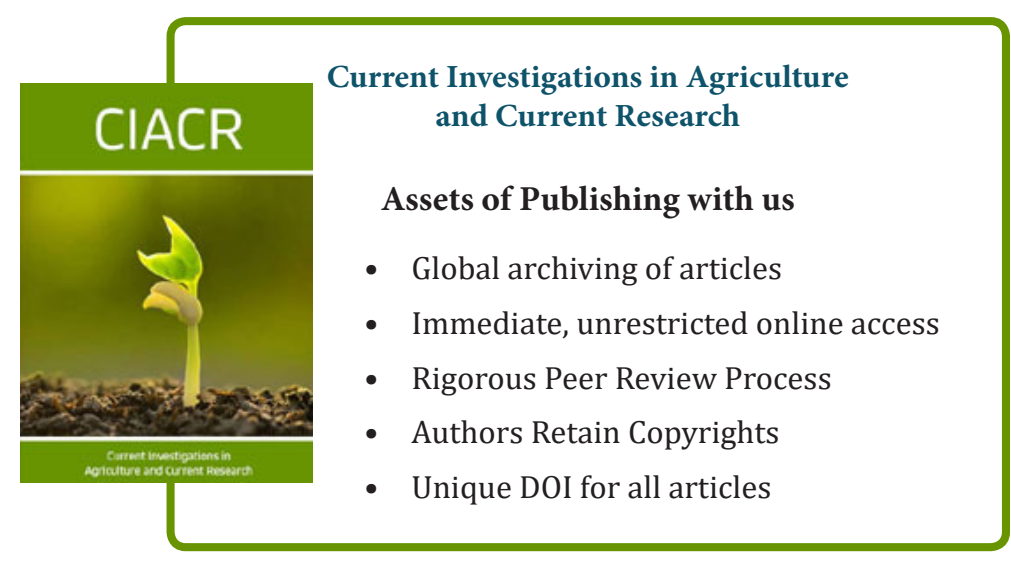

